\title{
ANALISIS NILAI TAMBAH PENGOLAHAN GULA KELAPA DI KABUPATEN OKU TIMUR
}

\author{
Ary Eko Prastya Putra
}

\author{
Sekolah Tinggi Ilmu Pertanian Belitang \\ Jln.Kampus Pertanian No.3 Belitang Kab.OKU Timur Prov.Sumatera Selatan \\ e-mail: ary.speed88@gmail.com
}

\begin{abstract}
The purposes of this research were to : (1) To calculate the amount of production cost that is expended and income earned in coconut sugar processing business in East OKU Regency, (2) To know the value of coconut sugar processing in East OKU Regency, (3) To know the level of coconut sugar business feasibility in East OKU Regency. This research was conducted in OKU Timur Regency, but there were only two sub-districts from 20 sub-districts doing coconut sugar processing business. Namely Belitang District III and Belitang Mulya District. For Belitang III District, there is one village that conducts coconut sugar processing business, that is Desa Switchwarno, and for Belitang Mulya Sub-district there are 5 villages doing coconut sugar processing business, namely Sugih Waras Village, Petanggan Village, Rejosari Village, and Srimulyo Village. Determining the location is done purposively (purposive sampling) with the consideration that in 5 villages are doing palm sugar processing business. While field research will be conducted in April 2013 until the completion. This research found that the production cost of coconut sugar processing business in East OKU Regency in one month of production is Rp 2,707,071.43 or Rp 32,484,857.16 / year, and the income earned in one business year is Rp 20,015,142,84 / year. The added value of coconut sugar processing business in OKU Timur Regency in one month of business is $R p$ 3,325,428.57 and Coconut sugar processing business in East OKU district is feasible to be developed with NPV value for 4 years ahead $R p$ 27,823,216.06, IRR 22.04\% and Net B / C 1.61.
\end{abstract}

Key Words : Value-added, Coconut sugar, and Income.

\section{PENDAHULUAN}

Indonesia memiliki lahan perkebunan kelapa terluas di dunia, dengan luas areal mencapai 3.860.000 hektar (Ha) atau 31,2\% dari total areal dunia sekitar 12.000.000 hektar (Ha). Berikut ini data persebaran kebun kelapa terbanyak di Indonesia.

Tabel 1. Data Persebaran Kebun Kelapa Terbanyak di Indonesia.

\begin{tabular}{|c|c|c|c|}
\hline No. & Pulau & Luas (Ha) & Persentase \\
\hline 1 & Sumatra & 1.331 .700 & $34,5 \%$ \\
\hline 2 & Jawa & 895.520 & $23,2 \%$ \\
\hline 3 & Sulawesi & 756.560 & $19,6 \%$ \\
\hline 4 & $\begin{array}{l}\text { Bali,NTB dan } \\
\text { NTT }\end{array}$ & 308.800 & $8,0 \%$ \\
\hline 5 & Kalimantan & 277.920 & $7,2 \%$ \\
\hline 6 & $\begin{array}{l}\text { Maluku dan } \\
\text { Papua }\end{array}$ & 289.500 & $7,5 \%$ \\
\hline 7 & Total & 3.860 .000 & $100 \%$ \\
\hline
\end{tabular}

Sumber: Dewan Kelapa Indonesia, 2009

Tabel diatas menunjukkan data persebaran kebun kelapa terbanyak dari pulaupulau besar yang ada di Indonesia. Pulau
Sumatera menduduki peringkat terbesar budidaya kelapa yaitu seluas 1.331.700 Ha dari luas total 3.860.000 Ha kemudian lokasi budidaya kelapa terbesar kedua adalah pulau jawa seluas 895.520 Ha. Untuk budidaya kelapa di pulau Sulawesi sendiri memiliki luas $756.560 \mathrm{Ha}$ dari luas total 3.860.000 Ha. Kemudian untuk pulau Bali,NTB, dan NTT luas areal perkebunan kelapa yaitu seluas $308.800 \mathrm{Ha}$ dari luas total 3.860.000 Ha. Untuk pulau Kalimantan sendiri memiliki luas areal perkebunan kelapa sebesar 277.920 Ha dari luas total 3.860.000 Ha. Sedangkan untuk pulau Maluku dan Papua memiliki luas area perkebunan kelapa seluas 289.500 Ha dari luas total 3.860.000 Ha.

Meskipun potensinya begitu besar secara nasional maupun di dunia, namun kelapa belum menjadi komoditas unggulan. Perlu dioptimalkan pengelolaannya sehingga kembali menjadi sebagai salah satu motor penggerak perekonomian nasional. Berbagai permasalahan masih dirasakan di tingkat petani, industri pengolah dan pada tingkat pemasaran. Permasalahan yang dihadapi juga beragam mulai dari teknis budidaya, skala 
usaha, teknologi pengolahan, pemasaran produk, sumber daya manusia, akses permodalan, infrastruktur, kesenjangan informasi dan dukungan kebijakan, (Dewan Kelapa Indonesia, 2009)

Gula kelapa merupakan jenis gula yang terbuat dari nira kelapa yaitu cairan yang dihasilkan dari penyadapan mayang tanaman kelapa. Gula kelapa sendiri sering dijadikan bahan pemanis makanan. Kebutuhan pemanis di Indonesia sebagian besar dipenuhi dari gula pasir yang berasal dari tebu. Pada tahun 2001, konsumsi gula nasional mencapai 3,3 juta ton per tahun. Hal tersebut tidak diimbangi dengan kemampuan kita dalam memproduksi gula yang kurang dari setengahnya atau sekitar 1,6 juta ton per tahun saja. Produksi gula nasional berarti hanya mampu mencukupi 50\% dari total kebutuhan gula nasional. Kekurangan produksi gula pasir untuk memenuhi kebutuhan gula dalam negeri menuntut adanya upaya untuk mencari bahan baku alternatif yang lebih murah dan mudah di dapat. Dalam kondisi ini gula kelapa memiliki peluang besar untuk memenuhi kekurangan konsumsi gula dalam negeri. Di samping itu, gula kelapa mempunyai kemungkinan untuk menjadi alternatif atau sebagai bahan subsitusi gula pasir karena pada umumnya masyarakat Indonesia khusunya masyarakat jawa, sudah mengenal gula kelapa dengan baik (Issoesetiyo dan T.Sudarto,2001).

Lahan perkebunan di Provinsi Sumatra Selatan memiliki potensi yang cukup baik untuk dikembangkan, diantaranya lahan perkebunan kelapa yang sudah digunakan seluas $67.738 \mathrm{Ha}$, dengan status kepemilikan lahan merupakan lahan perkebunan rakyat. Luas lahan tersebut tersebar di setiap kabupaten kota Provinsi Sumatra Selatan, termasuk salah satunya adalah Kabupaten OKU Timur (Statistik Perkebunan Indonesia 20092011).

Selain perkebunan karet dan kelapa sawit, di Kabupaten OKU Timur juga terdapat perkebunan lada, kelapa, coklat, dan perkebunan lainnya yang pada umumnya di kelola oleh rakyat. Berikut tabel luas areal dan total produksi tanaman perkebunan rakyat di Kabupaten OKU Timur.

Tabel 2. Luas Areal dan Total Produksi Tanaman Perkebunan di Kabupaten OKU Timur.

\begin{tabular}{ccccccc}
\hline No & $\begin{array}{c}\text { Tanaman } \\
\text { Perkebunan }\end{array}$ & $\begin{array}{c}\text { Luas Area } \\
(\mathrm{Ha})\end{array}$ & $\begin{array}{c}\text { Sudah } \\
\text { Berproduk } \\
\mathrm{si} \\
(\mathrm{Ha})\end{array}$ & $\begin{array}{c}\text { Belum } \\
\text { Berprodu } \\
\text { ksi } \\
(\mathrm{Ha})\end{array}$ & $\begin{array}{c}\text { Tidak } \\
\text { Berprodu } \\
\text { ksi } \\
(\mathrm{Ha})\end{array}$ & $\begin{array}{c}\text { Total } \\
\text { Produksi } \\
(\text { Ton })\end{array}$ \\
\hline 1 & Sawit & 44.229 & 10.727 & - & 33.502 & - \\
& perusahaan & & & & & \\
2 & Sawit rakyat & $2.762,4$ & 1.201 & $1.561,4$ & - & $4.470,14$ \\
3 & Karet & $29.442,269$ & 20.753 & $19.950,5$ & 9.488 & $74.577,52$ \\
4 & Kopi & $1.703,01$ & $1.548,5$ & 153,51 & 1 & $1.338,89$ \\
5 & Kelapa & $2.375,95$ & $1.603,5$ & 742,6 & 29,85 & $2.753,43$ \\
6 & Coklat & 435,5 & 275 & 178,5 & 7 & 392,1 \\
7 & Lada & $2.110,59$ & $1.991,49$ & 113,60 & 5,50 & $1.829,46$ \\
8 & Kemiri & 9,50 & 1 & 3,50 & - & 4,80 \\
9 & Aren & 22,50 & 15,50 & 7,00 & - & 5,20 \\
10 & Kapuk & 36,25 & 22,25 & 14,0 & - & 18,2 \\
\hline
\end{tabular}

Sumber: Dinas Kehutanan dan Perkebunan Kabupaten OKU Timur.

Dari tabel diatas bisa dilihat berapa luas area tanaman perkebunan yang ada di Kabupaten OKU Timur. Untuk tanaman perkebunan karet menduduki luas area yang paling luas di Kabupaten OKU Timur dengan luas area sebesar 29.442,269 $\mathrm{Ha}$, dan untuk tanaman perkebunan sawit rakyat menduduki peringkat kedua di Kabupaten OKU Timur, yaitu seluas 2.762,4 Ha, sedangkan untuk tanaman kelapa memiliki luas 2.375,95 Ha lebih rendah dari tanaman perkebunan sawit rakyat. Untuk tanaman perkebunan yang memiliki nilai rendah di Kabupaten OKU Timur adalah perkebunan kemiri, yang hanya memiliki luas area 9,50 Ha.

Usaha gula kelapa dimata pelaku usaha tetap memiliki peluang yang baik dimasa mendatang. Dengan potensi kelapa yang tinggi maka para pelaku usaha ini tetap berminat dan termotivasi untuk menekuni usaha gula kelapa yang di hasilkan dari nira kelapa. Apalagi kalau ada pembeli dari luar yang ingin menampung produk mereka, pasti banyak petani atau pelaku usaha lainnya yang meminati usaha gula kelapa ini(Anonim, 2015).

Kecamatan Belitang Mulya dan Kecamatan Belitang III merupakan kecamatan yang ada di Kabupaten OKU Timur yang mengelola usaha gula kelapa. Pembuatan gula kelapa bisa dikatakan masih sederhana, akan tetapi mampu meningkatkan pendapatan para petani dalam pemenuhan kebutuhan hidup. Usaha pengolahan gula kelapa di Kab. OKU Timur sangat bagus, karena di Kab. OKU Timur banyak pohon kelapa yang tumbuh di halaman pekarangan rumah petani, sehingga bahan baku pembuat gula kelapa mudah untuk didapat. Di Kecamatan Belitang Mulya dan Kecamatan Belitang III terdapat beberapa Desa yang melakukan usaha pengolahan gula kelapa ini, 
diantaranya yaitu Desa Sugih Waras, Desa Rejosari, Desa Petanggan, Desa Gantiwarno, dan Desa Srimulyo.

Berdasarkan latar belakang itu maka perlu diadakannya kajian mengenai Analisis Nilai Tambah Usaha Pengolahan Gula Kelapa di Kabupaten OKU Timur. Adapun tujuan dari penelitian ini penelitian sebagai berikut:

1. Untuk menghitung besarnya biaya produksi yang dikelurkan dan pendapatan yang di peroleh dalam usaha pengolahan gula kelapa di Kabupaten OKU Timur.

2. Untuk mengetahui nilai tambah pengolahan gula kelapa di Kabupaten OKU Timur.

3. Untuk mengetahui tingkat kelayakan usaha gula kelapa di Kabupaten OKU Timur.

\section{METODOLOGI PENELITIAN}

Penelitian ini dilaksanakan di Kabupaten OKU Timur, namun hanya ada dua kecamatan dari 20 kecamatan yang melakukan usaha pengolahan gula kelapa. Yaitu Kecamatan Belitang III dan Kecamatan Belitang Mulya. Untuk Kecamatan Belitang III ada satu desa yang melakukan usaha pengolahan gula kelapa ini, yaitu Desa Gantiwarno, dan untuk Kecamatan Belitang Mulya ada empat desa yang melakukan usaha pengolahan gula kelapa ini, yaitu Desa Sugih Waras, Desa Petanggan, Desa Rejosari, dan Desa Srimulyo. Penentuan lokasi dilakukan secara sengaja (purposive sampling) dengan pertimbangan bahwa di lima desa tersebut melakukan usaha pengolahan gula kelapa. Sedangkan penelitian lapangan akan dilaksanakan pada bulan April 2013 sampai dengan selesai. Metode yang digunakan dalam penelitian ini adalah metode survei dengan teknik sampling. Data yang dikumpulkan terdiri dari data primer dan data skunder. Data primer diperoleh dari hasil wawancara langsung dengan pengusaha gula kelapa, menggunakan daftar pertanyaan (quisioner) yang telah disiapkan sebelumnya. Sedangkan data skunder dipeoleh dari dinas, instasi dan lembaga yang ada hubungan dengan penelitian ini.

\section{A. Kerangka Pemikiran}

Gula kelapa adalah gula yang dihasilkan dari penguapan nira pohon kelapa. Gula kelapa atau dalam perdagangan disebut gula jawa, gula merah atau gula nira, biasanya di jual dalam bentuk setengah mangkok atau setengah elip. Bentuk demikian ini dihasilkan dari cetakan yang digunakan berupa setengah tempurung kelapa
( bathok :jawa ). Selain itu adapula yang menggunakan cetakan bambu, sehingga bentuknya bulat silindris. Gula merah kelapa diperoleh dari nira kelapa yang telah diuapkan dan dicetak dalam berbagai bentuk. Sampai saat ini, pembuatan gula kelapa dikerjakan oleh pengrajin tradisional dalam skala kecil dengan menggunakan peralatan-peralatan sederhana (Hidayat, 1998; Aryati, 2005).

Agribisnis adalah bisnis berbasis usaha pertanian atau bidang lain yang mendukungnya, baik di sektor hulu maupun hilir. Penyebutan "hulu" dan "hilir" mengacu pada pandangan pokok bahwa agribisnis bekerja pada rantai sektor pangan (food supply chain). Agribisnis, dengan perkataan lain, adalah cara pandang ekonomi bagi usaha penyediaan pangan. Sebagai subjek akademik, agribisnis mempelajari strategi memperoleh keuntungan dengan mengelola aspek budidaya, penyediaan bahan baku, pasca panen, proses pengolahan, hingga tahap pemasaran (Sjarkowi dan Sufri, 2004).

Pengetahuan tentang biaya produksi sangat di perlukan untuk menganalisa usaha agribisnis. Biaya produksi berupa sewa tanah, tenaga kerja, bahan-bahan perlengkapan produksi, peralatan dan biaya lainnya yang mungkin dikeluarkan selama masa pengolahan. Biaya produksi memiliki peranan penting dalam mengambil keputusan pada usaha agribisnis. Besarnya biaya yang akan dikeluarkan untuk memproduksi sesuatu harus diperhitungkan terhadap nilai penerimaan produksi yang di hasilkan (Soekartawi, 2002).

Pada dasarnya biaya produksi dibagi atas tiga bagian, yaitu biaya tetap, biaya variabel, dan biaya total. Biaya tetap adalah biaya yang dikeluarkan untuk membeli faktor-faktor produksi tetap, yang tidak tergabung pada produksi yang dihasilkan. Biaya tetap ini terdiri dari pajak, penyusutan alat-alat produksi, tanah atau sewa tanah dan lain-lain (Teken dan Asnawi, 2004). Biaya variabel adalah biaya yang habis dalam satu kali masa produksi yang digunakan untuk membeli faktor-faktor produksi, seperti sarana produksi, tenaga kerja dan lain-lain. Sedangkan biaya total merupakan biaya tetap di tambah biaya variabel tanpa memperhatikan hasil produksi apakah berlangsung dengan kenaikan produksi atau berkurangnya hasil produksi (Mubyanto, 2003).

Semakin banyak produk yang dihasilkan semakin besar total biaya yang digunakan tanpa 
memperhatikan kenaikan hasil bertambah atau berkurang. Biaya ini digunakan untuk menentukan pendapatan dari usaha dengan mengurangkannya pada penerimaan, dimana penerimaan adalah jumlah produksi dikalikan dengan harga. Proses produksi diartikan sebagai kegiatan merubah suatu barang menjadi barang lain sehingga mempunyai kegunaan yang lebih besar. Setiap kegiatan produksi tersebut membutuhkan biaya. Biaya merupakan nilai dari factor produksi yang digunakan untuk menghasilkan barang atau jasa. Biaya produksi adalah biaya-biaya yang dikeluarkan oleh petani dalam proses produksi serta membawanya menjadi hasil produksi. Biaya merupakan landasan bagi harga yang dapat diminta perusahaan untuk setiap produk yang dihasilkan (Sjarkowi dan Sufri, 2004).

Harga (price), hal ini selalu mempengaruhi penerimaan (revenue) sekaligus prilaku konsumen dan pesaing, agribisnis di sektor pertanian terutama usaha agribisnis gula kelapa pada umumnya bersifat penerima harga (price taker) bukan penentu harga (price maker). Harga merupakan nilai suatu barang atau jasa yang di tukar dengan sejumlah uang berdasarkan nilai tersebut, seorang atau pengusaha bersedia melepaskan barang atau jasa yang dimilikinya kepada pihak lain (Kristianto, 2005).

Penerimaan uang agribisnis dapat diartikan sebagai besaran keseluruhan hasil produksi yang diperoleh dari hasil produksi usaha agribisnis dan diberikan dengan harga yang berlaku saat itu didaerah/desa yang bersangkutan. Selanjunya didalam penerimaan usaha agribisnis tersebut tidak terlepas dari harga dan produk dimana petani akan menghasilkan suatu produk jika harga memadai (cukup tinggi). Hal ini sesuai dengan pendapat yang menyatakan bahwa harga salah satu produk sangat berpengaruh dalam pemasaran hasil pertanian (Kristianto, 2005).

Pendapatan adalah selisih antara penerimaan dengan biaya yang dikeluarkan dalam suatu kegiatan untuk mendapatka produksi dilapangan pertanian, karena petani bertindak sebagai pekerja dan penanam modal dalam usahatani maka pendapatan itu dapat digambarkan sebagai balas jasa dari pekerja factor produksi yang biayanya dalam jangka waktu tertentu (Soeharjo dan Patong, 2001).

Soekartawi (2004), menyatakan bahwa pendapatan kotor usahatani merupakan hasil perolehan total sumberdaya yang digunakan dalam usahatani, sedangkan pendapatan bersih usahatani merupakan selisih antara pendapatan kotor dan pengeluaran total usahatani. Pelaksanaan kegiatan usahatani bertujuan untuk memperoleh produksi dari lahan pertanian, pada akhirnya akan dinilai dari biaya yang dikeluarkan dan penerimaan yang diperoleh. Selisih antara penerimaan dengan biaya usahatani merupakan pendapatan dari kegiatan usahatani, besar kecilnya pendapatan yang diterima petani dipengaruhi oleh besarnya usaha, hasil yang diperoleh, efisiensi penggunaan tenaga kerja, pembagian usahatani, cara pemasaran serta cara penggunaan alat dan modal. Pendapatan pada usah pengolahan gula kelapa dipengaruhi oleh penerimaan dan biaya produksi. Petani dapat memperbesar keuntungan usahanya melalui langkah menekan biaya produksi atau langkah pengendalian pemasaran agar sebisa mungkin menaikkan harga jual. Apabila dalam menjalankan usaha biaya produksi baik biaya tetap maupun biaya variabel dapat ditekan seefisien mungkin maka akan menambah pendapatan petani pengolah gula kelapa. Pendapatan adalah arus masuk bruto dari manfaat ekonomi yang timbul dari aktivitas normal perusahaan selama suatu periode bila arus masuk ini mengakibatkan kenaikan ekuitas yang tidak berasal dari kontribusi penanam modal. Pendapatan sangat berpengaruh bagi kelangsungan hidup perusahaan, semakin besar pendapatan yang diperoleh maka semakin besar kemampuan perusahaan untuk membiayai segala pengeluaran dengan kegiatan-kegiatan yang akan dilakukan oleh perusahaan. Pendapat total adalah sama dengan jumlah unit output yang terjual di kalikan harga output perunit. Metode pendapatan memandang nilai output perekonomian sebagai nilai total balas jasa atau faktor produksi yang di gunakan dalam proses produksi. Biasanya makin tinggi tingkat pendapatan, tingkat konsumsi makin tinggi, karena tingkat pendapatan meningkat, kemampuan rumah tangga untuk membeli aneka kebutuhan konsumsi menjadi makin besar (Manurung dan rahardja, 2008).

Nilai tambah adalah kegiatan atau langkahlangkah dalam proses yang menambah atau mengubah suatu produk atau jasa. Ada dua cara untuk menghitung nilai tambah yaitu nilai tambah untuk pengolahan dan nilai tambah untuk pemasaran. Factor yang mempengaruhi nilai tambah pengolahan dapat dikategoorikan menjadi dua yaitu factor teknis dan factor pasar. Factor teknis yang berpengaruh adalah kapasitas 
produksi, jumlah bahan baku yang digunakan dan tenaga kerja. Factor pasar yang berpengaruh adalah harga output, upah tenaga kerja, harga bahan baku (Sudiyono, 2004).

Menurut Collins (1997), nilai tambah atau value added adalah nilai yang ditambahkan oleh suatu perusahaan terhadap bahan-bahan atau jasajasa yang dibelinya melalui produksi dan usahausaha pemasaran. Nilai tambah adalah selisih antara nilai output yang dihasilkan dengan harga bahan baku. Nilai tambah adalah perbedaan antara nilai dari output suatu perusahaan atau suatu industry yaitu total pendapatan yang diterima dari penjualan output tersebut dan biaya masukan dari bahan - bahan mentah, komponen-komponen atau jasa-jasa yang dibeli untuk memproduksi komponen tersebut. Nilai tambah adalah nilai output perusahaan atau industry dikurangi dengan nilai barang setengah jadi yang dibeli perusahaan. Untuk perekonomian secara menyeluruh jumlah seluruh nilai tambah harus sama dengan nilai seluruh barang dan jasa akhir (Mankiw, 2003).

Studi kelayakan usaha dibedakan menjadi tiga yaitu studi kelayakan teknis, studi kelayakan finansial, dan studi kelayakan ekologis. Studi kelayakan teknis merupakan langjkah persiapan formal yang paling awal untuk memulai suatu rencana usaha yang mengisyaratkan peran-peran dari adanya korbanan saprosi atau input berupa sumberdaya atau alami, insani dan buatan (Sjarkowi,2010).

Kriteria investasi yang digunakan dalam menentukan kelayakan suatu usahatani adalah dengan melihat nilai NPV, IRR, dan B/C Ratio (Gittinger, 1986 dalam Agustus, 1999). Menurut Pudjosumarto (2002), NPV adalah selisih antara benefit dengan cost yang telah di present valuekan. Proyek akan dipilih apabila NPV > 0. Gross B/C Ratio adalah perbandingan dari jumlah benefit kotor dengan biaya kotor dengan biaya yang telah dipresent valuekan. Proyek akan dipilih apabila $\mathrm{B} / \mathrm{C}$ Ratio > 1 . IRR merupakan tingkat bunga yang menggambarkan bahwa antara benefit yang telah dipresent valuekan dan cost yang telah dipresent valuekan sama dengan nol.

\section{B. Hipotesis}

Berdasarkan penelitian terdahulu dan kerangka pemikiran diagramatis, maka hipotesis dalam penelitian ini adalah :

1. Bahwa biaya produksi lebih kecil dari penerimaan sehingga diperoleh pendapatan dari usaha pengolahan gula kelapa di Kabupaten OKU Timur.

2. Bahwa usaha agribisnis pengolahan gula kelapa mempunyai nilai tambah.

3. Bahwa usaha pengolahan gula kelapa di Kabupaten OKU Timur layak untuk dikembangkan.

\section{Alat Analisis}

Data yang diperoleh dari lapangan diolah secara tabulasi lalu dianalisa menggunakan analisis deskriptif kuantitatif yaitu suatu metode penelitian menggunakan angka yang kemudian diolah, dianalisa dan ditarik kesimpulan yang menggambarkan objek yang diteliti.

Untuk menjawab hipotesis yang pertama, di gunakan beberapa rumus sebagai berikut :

1. Untuk menghitung biaya produksi (Soekartawi, 2002), dengan rumus :

$$
\mathrm{TC}=\mathrm{FC}+\mathrm{VC} .
$$

Keterangan :

$\mathrm{TC}=$ Total Cost/Biaya Produksi $(\mathrm{Rp})$

$\mathrm{FC}=$ Fixed Cost $/$ Biaya Tetap $(\mathrm{Rp})$

$\mathrm{VC}=$ Variabel Cost/Biaya Tidak Tetap $(\mathrm{Rp})$

2. Untuk menghitung penerimaan

(Soekartawi,2002), digunakan rumus :

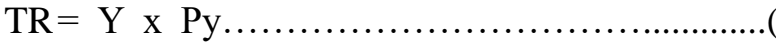

2)

Keterangan :

$\mathrm{TR}=$ Total Revenue/Total Penerimaan $(\mathrm{Rp})$

$\mathrm{Y}=$ Output Produksi/Hasil Produksi $(\mathrm{Kg})$

Py $=$ Price/Harga Jual $(\mathrm{Rp} / \mathrm{Kg})$

3. Untuk menghitung pendapatan ( Soekartawi, 2002), digunakan rumus :

$\mathrm{Pd}=\mathrm{TR}$

TC...................................... ( 3 )

Keterangan :

$\mathrm{Pd}=$ Income $/$ Pendapatan $(\mathrm{Rp})$

$\mathrm{TR}=$ Total Revenue $/$ Penerimaan $(\mathrm{Rp})$

$\mathrm{TC}=$ Total Cost $/$ Total Biaya Produksi $(\mathrm{Rp})$

Untuk menjawab hipotesis yang kedua, dapat digunakan rumus sebagai berikut : Untuk mengetahui nilai tambah ( Yudi, 2010) dari pengolahan gula kelapa dengan rumus :

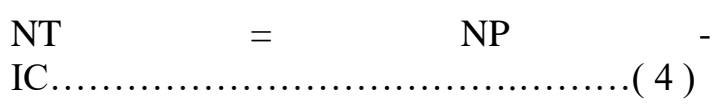


Keterangan :

NT $=$ Nilai Tambah

$\mathrm{NP}=$ Nilai Produk $/$ Penerimaan

IC $=$ Intermediate Cost / Biaya Antara (Kecuali tenaga kerja keluaga)

Untuk menjawab hipotesis yang ketiga, dapat digunakan rumus sebagai berikut :

1. Menurut Ibrahim, Y (2009). Untuk mengetahui tingkat kelayakan usaha dimana menjawab hipotesis ketiga digunakan rumus sebagai berikut :

$$
\mathrm{NPV}=\sum_{i=1}^{n} \frac{N B_{i}}{(1+i)^{n}}
$$

Keterangan :

NPV $=$ Net Present Value

$\mathrm{NB}=$ Net Benefit $=$ Benefit - Cost

$\mathrm{i} \quad=$ Tingkat Discount Faktor (bunga bank)

$\mathrm{n} \quad=$ Tahun (waktu)

Dengan kriteria :

NPV > 0 maka usaha layak untuk diusahakan

$\mathrm{NPV}=0$ break even point

NPV < 0 maka usaha tidak layak untuk diusahakan

2. Ibrahim. Y (2009). Untuk mengetahui tingkat bunga yang berlaku digunakan rumus sebagai berikut:

a.IRR $=i_{1}+\left[\frac{N P V_{1}}{N P V_{1-N P V_{2}}} X\left(i_{2}-i_{1}\right)\right]$

Keterangan :

$\mathrm{NPV}_{1}=\mathrm{NPV}$ pada tingkat discount rate tertinggi (positif)

$\mathrm{NPV}_{2}=\mathrm{NPV}$ pada tingkat discount rate tertinggi (negatif)

$\mathrm{i}_{1}=$ Discount rate $\mathrm{NPV}_{1}$

$\mathrm{i}_{2}=$ Discount rate $\mathrm{NPV}_{2}$

Kriteria yang dipakai :

IRR > Cost Of Capital maka layak

IRR $<$ Cost Of Capital maka tidak layak

b. Net $\mathrm{B} / \mathrm{C}=\frac{\sum_{i=1}^{n} \overline{N B}_{i}(+)}{\sum_{i=1}^{n} \overline{N B}_{i}(-)}$

Keterangan :

$\mathrm{NB}=$ Net Benefit

$\mathrm{n} \quad=$ Tahun Produksi(waktu)

$\mathrm{i} \quad=$ Discount Faktor

Kriteria yang dipakai :

Net $\mathrm{B} / \mathrm{C}>1$ Layak untuk dikerjakan

Net $B / C=1$ Break Even Point

Net $B / C<1$ Tidak layak untuk dikerjakan

\section{HASIL DAN PEMBAHASAN}

Dari hasil penelitian yang telah peniliti lakukan di 5 Desa yang berada di Kabupaten OKU Timur telah di peroleh data-data primer yang akan peneliti olah secara tabulasi dan matematis.

\section{Biaya Produksi}

Berdasarkan hasil penelitian usaha pengolahan gula kelapa banyak membutuhkan peralatan yang digunakan untuk usaha pengolahan gula kelapa mulai dari alat memasak, alat cetak , alat penderes dan lain-lain. Semua peralatan yang dibutuhkan oleh pengusaha olah gula kelapa harus siap ada dilokasi agar pembuatan lebih mudah. Besarnya biaya atau nilai rupiah yang dikeluarkan dalam pembuatan gula kelapa ini untuk pengadaan peralatan dan pembelian bahan-bahan yang dibutuhkan serta upah tenaga kerja dapat dilihat pada tabel berikut :

Tabel 3. Rata-rata Biaya Tetap Usaha Pengolahan Gula Kelapa di Kabupaten OKU Timur.

\begin{tabular}{clrrr}
\hline \multirow{2}{*}{ No } & \multicolumn{1}{c}{ Uraian } & \multicolumn{3}{c}{ Rata-rata } \\
\cline { 3 - 5 } & Rew/Tahun & \multicolumn{1}{c}{ Rp/Bulan } & \multicolumn{1}{c}{ Rp/Proses } \\
\hline 1 & Sewa Tempat & $1,500,000.00$ & $125,000.00$ & $4,166.67$ \\
2 & Tempat masak & $42,500.00$ & $3,541.67$ & 118.06 \\
3 & Wajan & $23,639.46$ & $1,969.95$ & 65.67 \\
4 & Sabit & $18,112.50$ & $1,509.38$ & 50.31 \\
5 & Drigen & $21,666.67$ & $1,805.56$ & 60.19 \\
6 & Meja & $10,133.33$ & 844.44 & 28.15 \\
7 & Ember & $4,000.00$ & 333.33 & 11.11 \\
8 & Sutil & $2,000.00$ & 166.67 & 5.56 \\
9 & Gayung & 800.00 & 66.67 & 2.22 \\
10 & Cetakan (Bumbung) & $1,171.88$ & 97.66 & 3.26 \\
11 & Kendaraan & $67,500.00$ & $5,625.00$ & 187.50 \\
\hline \multicolumn{7}{r}{ TOTAL } & $\mathbf{1 , 6 9 1 , 5 2 3 . 8 3}$ & $\mathbf{1 4 0 , 9 6 0 . 3 2}$ & $\mathbf{4 , 6 9 8 . 6 8}$ \\
\hline
\end{tabular}

Sumber: Data Primer, 2013.

Berdasarkan tabel diatas dapat diketahui bahwa rata - rata biaya tetap yang di keluarkan dalam usaha pengolahan gula kelapa selama satu bulan adalah sebesar Rp 140,960.32/bulan, yang terdiri dari biaya sewa gedung dan biaya penyusutan peralatan.

Bahan-bahan yang digunakan dalam usaha pengolahan gula kelapa tidak terlalu banyak. Semua biaya yang dikeluarkan untuk pengadaan bahan dan yang habis dalam satu kali pakai dalam usaha pengolahan gula kelapa di sebut dengan biaya variabel. Biaya variabel pada usaha pengolahan gula kelapa terddiri dari pemblian bahan baku, biaya transportasi dan biaya upah tenaga kerja.

Tabel 4. Rata-rata Variabel Usaha Pengolahan Gula Kelapa di Kabupaten OKU Timur. 


\begin{tabular}{|c|c|c|c|c|}
\hline \multirow[b]{2}{*}{ No } & \multirow[b]{2}{*}{ Uraian } & \multicolumn{3}{|c|}{ Rata-rata } \\
\hline & & Rp/Tahun & Rp/Bulan & Rpproses \\
\hline 1 & Air Nira & $8,400,000.00$ & $700,000.00$ & $23,333.33$ \\
\hline 2 & Ampas Kelapa & $322,000.00$ & $26,833.33$ & 894.44 \\
\hline 3 & Kapur Sirih & $96,000.00$ & $8,000.00$ & 266.67 \\
\hline 4 & Merang & $525,333.33$ & $43,777.78$ & $1,459.26$ \\
\hline 5 & Transportasi & $1,560,000.00$ & $130,000.00$ & $4,333.33$ \\
\hline & Total & $10,903,333.33$ & 908,611.11 & $30,287.04$ \\
\hline
\end{tabular}

Sumber: Data Primer, 2013.

Tabel 5. Upah Tenaga Kerja

\begin{tabular}{|c|c|c|c|c|c|c|c|}
\hline No & Uraian & $\begin{array}{l}\text { Jumlath } \\
(\mathrm{HOK})\end{array}$ & $\begin{array}{l}\text { Waktu } \\
\text { HOK }\end{array}$ & $\begin{array}{c}\text { Upph } \\
\text { (RppHOK)Proses }\end{array}$ & $\begin{array}{c}\text { Jumlalh } \\
(\mathrm{Ry}) \text { Proses }\end{array}$ & Jumlan (Ryp Bulazs) & $\begin{array}{c}\text { Jumlah } \\
\text { (Rpp Tabur) }\end{array}$ \\
\hline 1 & Nanjatt & 1 & 2JAM & $7,500.00$ & 7,50000 & $225,000,00$ & $2,700,000,00$ \\
\hline 2 & Pengoldhan & 2 & 6IAM & $22,000.00$ & $44,000.00$ & $1,320,000,00$ & $15,840,000,00$ \\
\hline 3 & Pencetalan & 2 & $0.5 \mathrm{JAM}$ & $1,875.00$ & $3,750,00$ & $112,500,00$ & $1,350,000,00$ \\
\hline & TOTAL & & & & $5,250,00$ & $1,667,000,00$ & 19,890,000,00 \\
\hline
\end{tabular}

Sumber: Data Primer, 2013.

Berdasarkan tabel ditas rata-rata biaya variabel yang di keluarkan dalam usaha pengolahan gula kelapa adalah Rp 2,566,111.11/bulan. Jadi rata-rata total biaya produksi yang dikeluarkan dalam usaha pengolahan gula kelapa adalah Rp 2,707,071.43/bulan atauRp32,484,857.16/tahun.

Tabel 6. Rata-rata Biaya Produksi Usaha Pengolahan Gula Kelapa di Kabupaten OKU Timur.

\begin{tabular}{|c|c|c|c|c|}
\hline No & Uraian & Nilai(Rpp Tahun) & Nilai(Rpp Bulan) & $\begin{array}{c}\text { Nilai } \\
\text { (RpProses) }\end{array}$ \\
\hline \multirow[t]{3}{*}{1} & Biaya Tetap & & & \\
\hline & - Serva Tempat & $1,500,000.00$ & $125,000.00$ & $4,166.67$ \\
\hline & Penyusutan Alat & $191,523.83$ & $15,960.32$ & 532.01 \\
\hline \multirow[t]{4}{*}{2} & Biaya Variabel & & & \\
\hline & - Biaya Operasional & $10,903,333.33$ & $908,611.11$ & $30,287.04$ \\
\hline & - Upah Tenaga Kerja & $19,890,000.00$ & $1,657,500.00$ & $55,250.00$ \\
\hline & Total & $32,484,857,16$ & $2,707,071.43$ & $90,235.71$ \\
\hline
\end{tabular}

Sumber: Data Primer, 2013.

Dari tabel di atas, untuk mengetahui hasil dari biaya penyusutan alat/tahun adalah jumlah seluruh biaya tetap di kurang dengan biaya sewa tempat/tahun.

\section{Produksi, Penerimaan dan Pendapatan}

Produksi yang dihasilkan oleh pengusaha pengolahan gula kelapa di Kabupaten OKU Timur adalah Gula Merah dari air nira kelapa. Gula yang dihasilakan merupakan kebutuhan konsumen setiap hari atau pesanan dari konsumen. Berikut tabel produksi dan penerimaan usaha pengolahan gula kelapa di Kabupaten OKU Timur:

Tabel 7. Rata-rata Produksi dan Penerimaan Usaha Pengolahan Gula Kelapa di Kabupaten OKU Timur.
No Sampel Penerimaan/Tahun Penerimaan/Bulan Penerimaan proses

\begin{tabular}{ccccc}
\hline 1 & 1 & $70,200,000.00$ & $5,850,000.00$ & $195,000.00$ \\
2 & 2 & $54,000,000.00$ & $4,500,000.00$ & $150,000.00$ \\
3 & 3 & $37,800,000.00$ & $3,150,000.00$ & $105,000.00$ \\
4 & 4 & $43,200,000.00$ & $3,600,000.00$ & $120,000.00$ \\
5 & 5 & $75,600,000.00$ & $6,300,000.00$ & $210,000.00$ \\
6 & 6 & $43,200,000.00$ & $3,600,000.00$ & $120,000.00$ \\
7 & 7 & $48,600,000.00$ & $4,050,000.00$ & $135,000.00$ \\
8 & 8 & $40,500,000.00$ & $3,375,000.00$ & $112,500.00$ \\
9 & 9 & $59,400,000.00$ & $4,950,000.00$ & $165,000.00$ \\
\hline \multicolumn{2}{l}{ Rata-rata } & $52,500,000.00$ & $4,375,000.00$ & $145,333.33$ \\
\hline
\end{tabular}

Sumber: Data Primer, 2013.

Besarnya rata-rata yang diperoleh dalam usaha pengolahan gula kelapa dalam satu bulan adalah $\mathrm{Rp} 4,375,000.00 /$ bulan atau $\mathrm{Rp}$ $52,500,000.00 /$ tahun. Jadi besarnya pendapatan yang di peroleh dari usaha pengolahan gula kelapa di Kabupaten OKU Timur selama satu tahun produksi adalah $\mathrm{Rp} 52,500,000.00 \quad-\mathrm{Rp}$ $32,484,857.16=\operatorname{Rp} 20,015,142.84 /$ tahun.

Tabel 8. Pendapatan Usaha Pengolahan Gula Kelapa di Kabupaten OKU Timur.

\begin{tabular}{|c|c|c|c|c|}
\hline \multirow{2}{*}{ No } & \multirow{2}{*}{ Uraian } & \multicolumn{3}{|c|}{ Nilai } \\
\hline & & Rpp/Tahun & Rppilan & Rpproses \\
\hline 1 & Nilai Produksi Penerimaan & $52,500,000.00$ & $4,375,000.00$ & $145,833.33$ \\
\hline 2 & Biaya Produksi & $32,484,857.16$ & $2,707,071.43$ & $90,235.71$ \\
\hline & Pendapatan & $20,015,142.84$ & $1,667,928.57$ & $55,597,62$ \\
\hline
\end{tabular}

Sumber: Data Primer, 2013.

3. Nilai Tambah

Nilai tambah pada penelitian ini adalah nilai tambah pada pengolahan gula kelapa yang ada di kabupaten OKU Timur. Adapun yang dimaksud dalam nilai tambah ini adalah membandingkan suatu pendapatan yang diperoleh dari tanaman perkebunan kelapa apabila dijual dalam bentuk buah kelapa yang sudah tua dengan di jual dari hasil penyadapan bunga mayang berupa air nira yang diolah menjadi gula kelapa atau gula merah.

Pengolahan gula kelapa yang di kelola para usaha pengolahan gula kelapa di Kabupaten OKU Timur akan meningkatkan nilai tambah financial dari produk yang dihasilkan. Besarnya nilai tambah yang di terima di pengaruhi oleh beberapa factor yaitu kualitas produk yang dihasilkan dan harga yang diterima dari produk yang dihasilkan. Dalam pengolahan gula kelapa 
setiap 5 liter air nira jika di olah menjadi gula kelapa bisa menghasilkan 1-1.5 Kg gula kelapa.

Biaya antara adalah biaya operasional yang dikeluarkan dalam proses pembuatan produk usaha gula kelapa, namun biaya tenaga dalam keluarga tidak diperhitungkan. Nilai tambah produk pengolahan gula kelapa diperoleh dari selisih antara nilai produk dan biaya antara. Berikut rumus mencari nilai tambah menurt Yudi 2010:

NT $=$ NP-IC

Dimana :

NT : Nilai Tambah

NP : Nilai Produk

IC : Biaya Antara

Maka :

$\mathrm{NT}=\mathrm{Rp} 52,500,000.00-\mathrm{Rp} 12,594,857.16$

$\mathrm{NT}=\mathrm{Rp} 39,905,142.84 / \mathrm{Tahun}, \mathrm{Rp} 3,325,428.57 /$ Bulan,

\section{Rp 110,847.62/Proses}

Dibandingkan dengan penjualan buah kelapa tua, penjualan dalam bentuk gula hasilnya lebih tinggi. Untuk pendapatan yang diperoleh dalam penjualan bentuk buah kelapa tua yaitu $\mathrm{Rp}$ $1,392,900.00$ / Tahun, dalam 30 batang pohon kelapa. Jadi selisih antara di jual dalam bentuk buah tua dengan bentuk gula adalah $\mathrm{Rp}$ 18,622,241.84/Tahun,atau Rp 1,551,853.57/Bulan.

Selain nilai tambah secara financial bagi pelaku usaha, usaha pengolahan gula kelapa juga menjadi nilai tambah bagi tenaga kerja yang turut memproduksi usaha pengolah gula kelapa sehingga ada beberapa keluarga yang dapat tercukupi kebutuhan hidupnya karena usaha pengolahan gula kelapa yang ada di Kabupaten OKU Timur serta mengurangi jumlah pengangguran yang ada di Kabupaten OKU Timur.

\section{Kelayakan Usaha}

\section{Net Present Value}

Untuk mengetahui apakah usaha pengolahan gula kelapa di kabupaten OKU Timur ini layak untuk dikembangkan untuk tahun tahun kedepan maka akan di gunakan rumus perhitungan NPV untuk mengetahui perkiraan keuntungan yang akan diperoleh untuk 4 tahun kedepan.

Ada beberapa hal yang harus dihitung untuk mengetahui nilai NPV yang akan diperoleh yaitu menghitung modal awal atau investasi yang di keluarkan pada usaha pengolahan gula kelapa. Biaya awal yang di keluarkan yaitu untuk pembelian lokasi usaha dan pembelian peralatan yang di gunakan untuk usaha pengolahan gula kelapa.

Tabel 9. Investasi Awal Modal Awal Usaha Pengolahan Gula Kelapa.

\begin{tabular}{clc}
\hline \multirow{2}{*}{ No } & \multicolumn{1}{c}{ Uraian } & $\begin{array}{l}\text { Jumlah } \\
\text { Ivestasi }\end{array}$ \\
\hline 1 & Pembelian lokasi usaha & $42,777,777.78$ \\
2 & Pengadaan peralatan & $2,684,722.22$ \\
\hline & Total Biaya Investasi & $45,462,500.00$ \\
\hline
\end{tabular}

Sumber: Data Primer, 2013.

Langkah selanjutnya menghitung besarnya biaya operasional yang di keluarkan dalam usaha pengolahan gula kelapa. Biaya operasional usaha pengolahan gula kelapa terdiri dari biaya sewa tempat, penyusutan peralatan, pengadaan bahan,transportasi dan tenaga kerja.

Tabel 10. Biaya Operasional Usaha Pengolahan Gula Kelapa di Kabupaten OKU Timur.

\begin{tabular}{|c|c|c|c|c|}
\hline No & Uraian & $\begin{array}{c}\text { Jumlah } \\
\text { (Rp/Tahun) }\end{array}$ & $\begin{array}{c}\text { Jumlah } \\
\text { (Rppulan) }\end{array}$ & $\begin{array}{c}\text { Jumlah } \\
\text { (Rpp Proses) }\end{array}$ \\
\hline 1 & Seva Tempat & $1,500,000.00$ & $125,000.00$ & $4,166.67$ \\
\hline 2 & Pengadaan Peralatan & $191,523.83$ & $15,960.32$ & 532.01 \\
\hline 3 & Pengadaan Bahan & $9,343,3333.33$ & $778,611.11$ & $25,953.70$ \\
\hline 4 & Biaya Transportasi & $1,560,000.00$ & $130,000.00$ & $4,333.33$ \\
\hline 5 & Tenaga Kerja & $19,890,000.00$ & $1,657,500.00$ & $55,250.00$ \\
\hline Tot & aya Operasional & $32,484,8577.16$ & 2,707,071.43 & $90,235.71$ \\
\hline
\end{tabular}

Sumber: Data Primer, 2013.

Setelah di ketahui besarnya modal awal dan biaya operasional langkah selanjutnya adalah menghitung nilai NPV usaha pengolahan gula kelapa.

Hasil perhitungan kriteria investasi dapat digunakan sebagai bahan pertimbangan dalam mengambil keputusan penanaman modal. Criteria investasi yang digunakan : NPV, IRR, Net B/C. keputusan yang timbul dari hasil analisis menerima atau menolak, memilih satu atau beberrapa proyek, atau menetapkan skala prioritas dari proyek yang layak ( Ibrahim,2009).

Ada beberapa hal yang harus dihitung untuk mengetahuinilai NPV yang akan di peroleh yaitu menghitung nilai modal atau investasi yang di keluarkan pada usaha pengolahan gula kelapa.

Untuk mengetahui pengolahan gula kelapa menguntungkan atau tidak, dapat di nilai dengan menggunakan analisa NPV,IRR pada suku bang tertentu, dan Net B/C.

Tabel 11. Analisis Net Present Value Usaha Gula Kelapa di Kabupaten OKU Timur. 


\begin{tabular}{|c|c|c|c|c|c|}
\hline Tahum & $\begin{array}{c}\text { InvestasiModal } \\
\text { Awal(Ma) }\end{array}$ & $\begin{array}{c}\text { Biaya } \\
\text { Operasional } \\
\text { (BO) }\end{array}$ & Total Cost $(T C)$ & Benefit(B) & Net Benefit(NB) \\
\hline 0 & $45,462,500,00$ & & $45,462,500.00$ & & $(45,462,500.00)$ \\
\hline 1 & & $32,484,857.16$ & $32,484,857.16$ & $52,500,000.00$ & $20,015,142.84$ \\
\hline 2 & & $32,484,857.16$ & $32,484,857.16$ & $57,750,000000$ & $25,265,142.84$ \\
\hline 3 & & $32,484,857.16$ & $32,484,857.16$ & $63,525,000000$ & $31,040,142.84$ \\
\hline 4 & & $32,484,857.16$ & $32,484,857.16$ & $69,877,500.00$ & $37,392,642.84$ \\
\hline NPV & & & & & \\
\hline
\end{tabular}

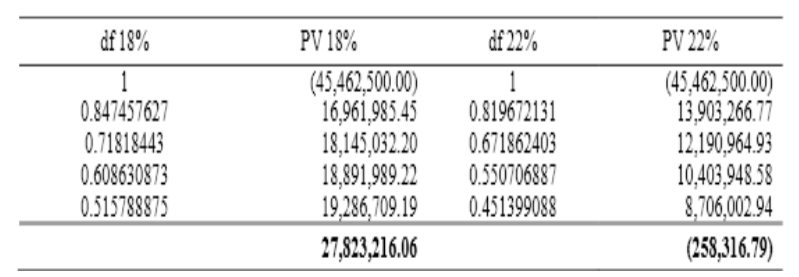

Sumber: Data Primer, 2013.

Dari hasil tabel diatas di peroleh nilai investasi awal untuk pembelian lahan dan alat-alat produksi adalah sebasar $\mathrm{Rp}$ 45,462,500.00 sehingga pendapatan pada tahun ke 0 adalah Rp 45,462,500.00. Dari perhitungan NPV selama empat tahun dengan suku bunga bank sebesar $18 \%$ maka di peroleh nilai NPV adalah sebesar Rp 27,823,216.06 dan nilai NPV > 0, hal ini menunjukkan bahwa usaha pengolahan gula kelapa di kabupaten OKU Timur ini menguntungkan dan layak untuk di kembangkan.

2. Analisis IRR (Internal Rate of Return)

IRR menunjukkan kemampuan suatu usaha dalam menghasilkan keuntungan. Criteria yang dapat di gunakan untuk menunjukkan bahawa suatu usaha layak untuk di jalankan jika nilai IRR lebih besar dari tingkat suku bunga yang berlaku pada saat usaha tersebut di jalankan. Untuk menghitung besarnya nilai IRR maka harus di ketahui dahulu berapa nilai dari NPV negative pada suku bunga tertentu. Untuk NPV negative pada usaha pengolahan gula kelapa ini di hasilkan pada suku bunga $22 \%$. Untuk lebih jelas dapat di lihat pada tabel berikut:

Tabel 12. Analisis Perhitungan IRR Usaha Pengolahan Gula Kelapa di Kabupaten OKU Timur.

\begin{tabular}{|c|c|c|c|c|c|}
\hline $\operatorname{IPV}(+)$ & $\operatorname{MPV}(\cdot)$ & $\begin{array}{l}\mathbb{P V V}(+) \cdot \\
\mathbb{N P V}(\cdot)\end{array}$ & $\operatorname{NPV}(-) \operatorname{RV}(+) \cdot \operatorname{PPV}(\cdot)$ & (i.i.i.) & $\mathbb{R R}$ \\
\hline $27,823,2160.06$ & $258,316.90$ & $27,364,999.28$ & 1.0937 & 0.04 & $22 . \mathrm{A}_{4}$ \\
\hline
\end{tabular}

Sumber: Data Primer, 2013.

$$
\begin{aligned}
& I R R=i_{1}+\frac{N P V_{1}}{\left(N P V_{1}-N P V_{2}\right)} X\left(i_{2}-i_{1}\right) \\
& \operatorname{IRR}=18 \%+\frac{27,823,216.06}{27,564,899.28} \times(22 \%-18 \%) \\
& \operatorname{IRR}=18 \%+\quad 1.009371222 \quad \times 4 \% \\
& \operatorname{IRR}=\quad 0.2204 \\
& \operatorname{IRR}=\quad 22.04 \%
\end{aligned}
$$

Nilai IRR usaha pengolahan gula kelapa adalah $22.04 \%$ yang berarti lebih besar dari suku bunga bank yaitu 18\%/ tahun, jadi usaha pengolahan gula kelapa layak untuk dikembangkan.

3. Analisis Net B/C

Net $B / C$ mmerupakan salah satu alat kajian yang digunakan untuk menganalisis suatu proyek yang akan dijalankan. Jika nilainya lebih besar dari 1 maka dinyatakan layak.

$$
\begin{aligned}
\text { Net } B / C & =\frac{\sum_{i=1}^{n} N \bar{B} i(+)}{\sum_{i=1}^{n} N \bar{B} i(-)} \\
\text { Net } B / C & \frac{73,285,716.06}{45,462.500 .00} \\
& =\frac{C 1.61}{}
\end{aligned}
$$

Hasil Net B/C pada usaha pengolahan gula kelapa berdasarkan perhitungan diatas, menunjukkan bahwa nilai Net $\mathrm{B} / \mathrm{C}$ pada discount rate $18 \%$ adalah sebesar 1.61. karena nilainya berada di atas satu maka dapat dinyatakan bahwa selama waktu 4 tahun yang akan datang usaha pengolahan gula kelapa layak untuk di kembangkan.

4. Gambaran Pemasaran Hasil Pengolahan Gula Kelapa

Gula kelapa merupakan bahan pemanis yang terbuat dari hasil olahan air nira pohon kelapa, yang biasanya digunakan sebagai pemanis minuman, dan aneka makanan. Bahan pemanis dari gula kelapa merupakan pemanis yang aman untuk di konsumsi.dengan harga yang terjangkau, sehingga semua kalangan masyarakat dapat merasakannya.

Untuk pemasaran gula kelapa ini rata rata pedagang datang langsung ke tempat usaha pengolahan gula kelapa, namun terkadang produsen menjual sendiri hasil produksinya dan ada juga konsumen datang langsung untuk 
membeli gula kelapa. Untuk rantai pemasaran gula kelapa ini tidak terlalu panjang yaitu dari produsen-pengecer/pedagang-konsumen,

produsen-konsumen.

Untuk volume penjualan produsen menjual hasil produksinya ( Gula kelapa) seharga $\mathrm{Rp} 15,000.00 / \mathrm{kg}$. Biasanya pengolahan gula kelapa ini dalam pengolahan bahan baku(air nira) menjadi gula kelapa untuk mendapatkan gula $1 \mathrm{~kg}$ menghabiskan bahan air nira sebanyak \pm 5 liter air nira. Dan untuk setiap $1 \mathrm{~kg}$ terdapat 40 biji gula kelapa dengan ukuran biasanya.

Rendemen 5 liter air nira : 2-3 batang pohon kelapa : $1 \mathrm{~kg}$ gula kelapa 5 liter nira : $1 \mathrm{~kg}$ gula $=$ $5: 1=20 \%$

\section{IV.KESIMPULAN DAN SARAN}

\section{A. Kesimpulan}

Berdasarkan hasil penelitian dan pembahasan usaha pengolahan gula kelapa di Kabupaten OKU Timur, maka di peroleh kesimpulan sebagai berikut :

1. Biaya produksi usaha pengolahan gula kelapa di Kabupaten OKU Timur dalam satu bulan produksi adalah $\mathrm{Rp} 2,707,071.43 \mathrm{atau}$ Rp 32,484,857.16/ tahun, dan pendapatan yang di peroleh dalam satu tahun usaha adalah Rp 20,015,142.84/tahun.

2. Nilai tambah pada usaha pengolahan gula kelapa di Kabupaten OKU Timur dalam satu bulan usaha adalah $\mathrm{Rp} \mathrm{3,325,428.57}$

3. Usaha pengolahan gula kelapa di kabupaten OKU Timur layak untuk di kembangkan dengan nilai NPV untuk 4 tahun kedepan Rp 27,823,216.06, IRR 22.04\%, dan Net B/C 1.61 .

\section{B. Saran}

Berdasarkan hasil dan kesimpulan maka penulis dapat menyarankan bahwa usaha pengolahan gula kelapa di kabupaten OKU Timur agar lebih di kembangkan dengan memproduksi lebih banyak dengan tetap menjaga kualitas produk, yang diimbangi dengan meningkatkan pangsa pasar. Usaha pengolahan gula kelapa yang ada di Kabupaten OKU Timur ini memberikan pengaruh yang besar terhadap pendapatan keluarga. Dan juga Agar pemerintah menciptakan home industry yang menggunakan bahan baku gula kelapa, sehingga dapat memacu produksi gula kelapa.

\section{DAFTAR PUSTAKA}

Ariadi B. Yudi dan R. Relawati. 2010. System Agribisnis Terintegrasi Hulu-Hilir. Muara Indah. Bandung.

Aryati, A. 2005. Pengaruh Cara Pelapisan dan Lama Simpan Terhadap Kadar Air, Tekstur dan Penampakan Gula Kelapa. Skripsi. Univesitas Lampung.

BPP ISMPI. 2009. Kondisi Pertanian Indonesia Saat Ini Berdasarkan Pandangan Mahasiswa Pertanian Indonesia. Topik Berita(Topik Berita).

Departemen Pertanian. 2007. Kebijakan Teknis Program Pengembnagan Usaha Agribisnis. Jakarta.

Dewan Kelapa Indonesia. 2009. http://www.Dekindo.com/media.php ?artikel=1 [diakses pada 15 April 2013 pkl. 17.00 WIB].

Gittinger , J.P. 1986. Analisa Ekonomi ProyekProyek Pertanian. Edisi Kedua. Universitas Indonesia. Jakarta.

Ibrahim Yacob, H. M. 2003. Studi Kelayakan Bisnis, Edisi Revisi. PT. Rineka Cipta. Jakarta.

Ibrahim, Y. 2009. Studi Kelayakan Bisnis jilid 1. Rineka Cipta. Jakarta.

Issoesetiyo dan T.Sudarto. 2001. Gula Kelapa Produk Hilir Sepanjang Masa. Arkola. Surabaya.

Kristianto. 2005. Pemasaran Produksi. Jakarta.

Mankiw, N. Gregory. 2003.Teori Makro Ekonomi Terjemahan. PT. Gramedia Pustaka Utama. Jakarta.

Manullang, M.2000. Manajemen Personalia.Yogyakarta: Gadjah MadaUniversity Press.

Mubyanto. 2003. Pengantar Ekonomi Pertanian Edisi Ketiga. LP3ES. Jakarta

Nasution, S. 2004. Metode Research. Bumi Aksara. Jakarta. 
Pratama Rahardja dan Mandala Manurung, 2008. Teori Ekonomi Makro : Suatu Pengantar. Lembaga Penerbit FE UI.

Pudjosumarto, M. 2002. Evaluasi Proyek Uraian Singkat dan Soal Jawaban. Liberty, Yogyakarta.

Sigit. 2002. Analisis Pemasaran. Pustaka Putra. Jakarta. .

Sjarkowi, F. dan M. Sufri. 2004. Manajemen Agribisnis. Palembang: CV. Baldal

Soeharjo dan Patong. 2001. Sendi-Sendi Pokok Ilmu Usahatani. Departemen Ilmu Ilmu Sosial Ekonomi Pertanian. IPB. Bogor.

Soekartawi. 2002. Analisis Usahatani. Universitas Indonesia (UI Pres). Jakarta.

Sudiyono, A.2004. Pemasaran Pertanian. Universitas Muhamadiyah Malang. Malang.
Tarigan, R. 2004. Ekonomi Regional. Bumi Aksara. Jakarta.

Teken dan Asnawi. 1997. Penelitian dibidang Ilmu Ekonomi Pertanian dan Beberapa Metode Pengambilan Contoh. Fakultas Pertanian. IPB. Bogor.

Teken, I. B dan Asnawi, S. 2004. Teori Ekonomi Mikro. Departemen Ilmu-ilmu Sosial Ekonomi. Institut pertanian Bogor. 


\section{$\underline{\text { Lampiran 1. Model Pendektan Diagramatik }}$}

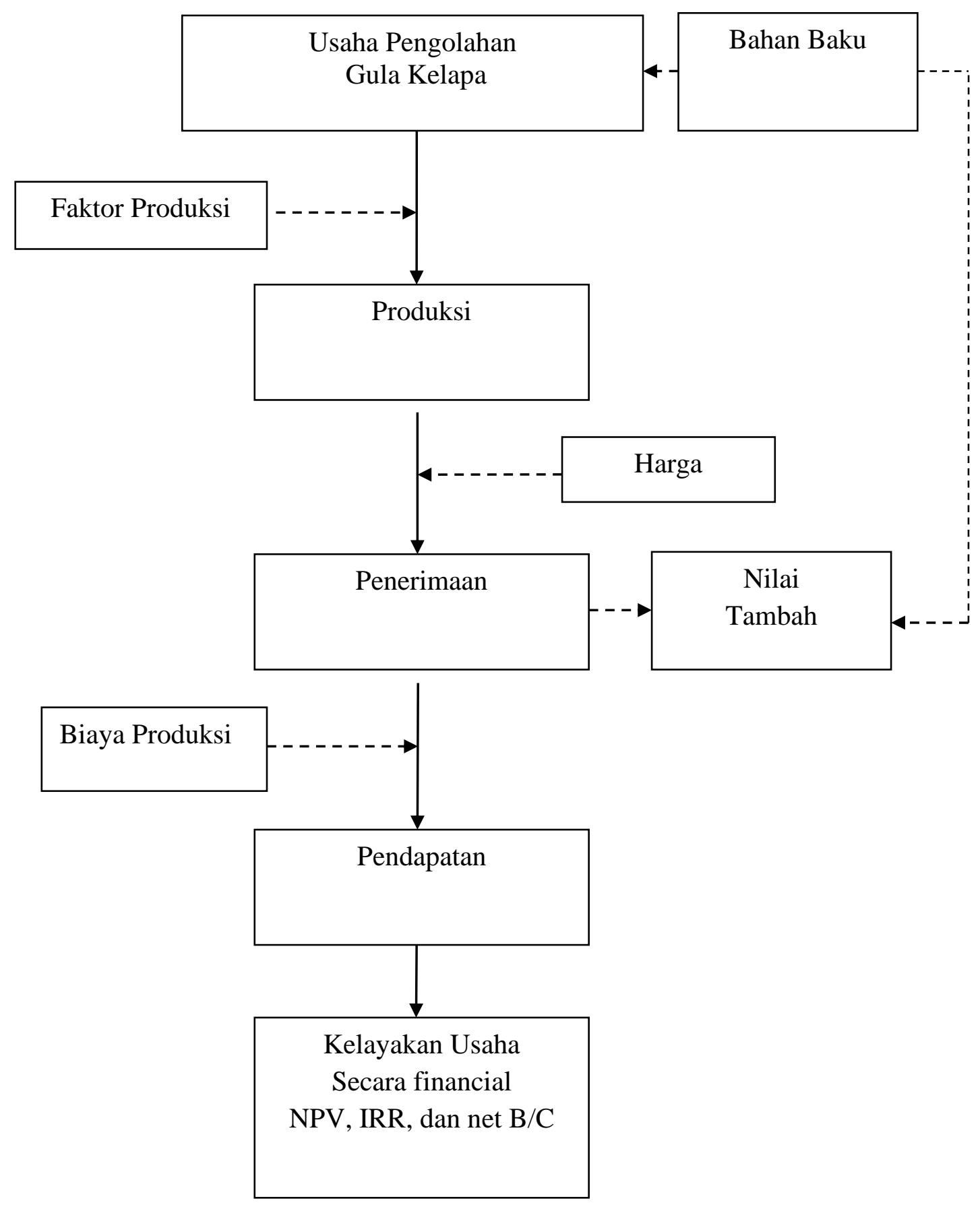

